\title{
PENGARUH PENGGUNAAN UBI JALAR UNTUK SUBSTITUSI TERIGU YANG DIFORTIFIKASI DENGAN TEPUNG KORO PEDANG (Canavalia ensiformis L. DC) DALAM PEMBUATAN MIE KERING
}

\author{
THE EFFECT OF SWEET POTATOES FOR SUBSTITUTION OF WHEAT FLOUR WHICH \\ BE ENRICHED WITH JACK BEAN FLOUR (Canavalia ensiformis L. DC) IN MAKING DRY \\ NOODLES
}

\author{
Achmad Ridwan A., Sri Handajani, Windi Atmaka, Nur Heryadi P \\ Program Studi Ilmu dan Teknologi Pangan, Fakultas Pertanian, Universitas Sebelas Maret Surakarta
}

Email: ridwan030586@gmail.com

\begin{abstract}
In this time, noodles have been used as one of the food substitution of rice but up to now wheat flour as its raw material is imported; while sweet potatoes as carbohydrate source could become substitution for flour. But the sweet potatoes are lack of protein. That is why to increase the protein content, the noodles in this research has been enriched with jack bean flour. The aim of this research was to study the effect of sweet potatoes substitution and jack bean flour enrichment for wheat flour to its chemical content and sensory characteristics of dry noodles. This research treatment are steamed sweet potato variation $(0 \%, 5 \%, 10 \%$ and $15 \%)$ to the flour and concentration of jack bean flour $(0 \%, 5 \%, 10 \%$ and $15 \%)$ to the mixture flour. The chemical analyse consist of moisture, ash, and protein content and also sensory characteristics (colour, taste, smell, elasticity and overall) of the dry noodles. This research use factorial plan and then data be analyzed statistically with Anova and DMRT. Result of the research show the higher concentration of steamed sweet potatoes, higher the moisture and ash content of the dry noodles, but lower the protein content and the lower preference of panellist for colour, taste, smell, elasticity and overall of the dry noodles. The higher concentration of jack bean flour, higher the protein and ash content, but lower the moisture content and the lower preference of panellist for colour, taste, smell, elasticity and overall of the dry noodles. The dry noodles which consist of $100 \%$ wheat flour, $0 \%$ steamed sweet potatoes and $5 \%$ jack bean flour (TOK1) is not significant difference with control (100\% wheat flour) and the dry noodles which consist of $95 \%$ wheat flour, $5 \%$ steamed sweet potatoes and $5 \%$ jack bean flour (TIKO) is also not significant difference with control for overall preference. That noodles fulfil the standard quality dry noodles according to SNI 1992. The TOK1 has moisture content of 10,412\% db, ash 1,430 $\% d b$, and protein 16,222 \% db; while T1K0 has moisture content of 10,795\% db, ash 1,209\% $\mathrm{db}$, and protein $16,801 \% d b$.
\end{abstract}

Keywords : Dry Noodles, Jack Bean Flour, Steamed sweet potatoes

\begin{abstract}
ABSTRAK
Tujuan penelitian ini adalah mempelajari pengaruh substitusi ubi jalar dan pengayaan tepung koro pedang terhadap tepung terigu pada kandungan kimia dan sifat sensoris mie kering. Perlakuan pada penelitian ini adalah variasi penggunaan ubi jalar kukus $(0 \%, 5 \%, 10 \%$ dan $15 \%)$ terhadap tepung terigu dan konsentrasi tepung koro pedang $(0 \%, 5 \%, 10 \%$ dan $15 \%)$ dari tepung campuran. Analisis kimia meliputi kadar air, abu dan protein serta uji sensoris (warna, rasa, aroma, elastisitas dan keseluruhan) mie kering. Penelitian ini menggunakan rancangan faktorial dan selanjutnya data dianalisis secara statistik dengan Anova dan DMRT. Hasil penelitian menunjukkan semakin tinggi penambahan ubi jalar kukus, maka semakin tinggi kadar air dan kadar abu mie kering, tetapi semakin rendah kadar protein mie kering serta semakin menurunkan penilaian panelis terhadap warna, rasa, aroma, elastisitas dan keseluruhan mie kering. Semakin tinggi penambahan tepung koro pedang yang digunakan, maka semakin tinggi kadar protein dan kadar abu mie kering, tetapi semakin rendah kadar air mie kering serta semakin menurunkan penilaian penelis terhadap warna, rasa, aroma, elastisitas dan keseluruhan mie kering. Mie kering yang terdiri dari $100 \%$ tepung terigu, $0 \%$ ubi jalar kukus dan $5 \%$ tepung koro pedang (T0K1) tidak berbeda nyata dengan kontrol (100\% tepung terigu) dan mie kering yang terdiri dari $95 \%$ tepung terigu, $5 \%$ ubi jalar kukus dan $0 \%$ tepung koro pedang (T1K0) juga tidak berbeda nyata dengan kontrol dari segi penilaian keseluruhan. Mie kering tersebut memenuhi syarat mutu mie kering sesuai dengan SNI 1992. Untuk T0K1 mempunyai kadar air sebesar 10,412 \% bk, kadar abu sebesar 1,430 \% bk, dan kadar protein sebesar 16,222 \% bk, sedangkan T1K0 mempunyai kadar air sebesar 10,795 \% bk, kadar abu sebesar 1,209 \% bk, dan kadar protein sebesar 16,801 \% bk.
\end{abstract}

Kata kunci : Mie Kering, Tepung Koro pedang, Ubi Jalar Kukus 


\section{PENDAHULUAN}

Saat ini, mie telah digunakan sebagai salah satu pangan pengganti nasi. Hal ini tentu sangat menguntungkan ditinjau dari sudut pandang penganekaragaman konsumsi pangan agar masyarakat kita tidak terlalu bergantung kepada beras sebagai makanan pokok. Mie mempunyai banyak keunggulan dan disukai banyak masyarakat Indonesia dalam hal tekstur, rasa, kenampakan, dan kepraktisan penggunaannya (Astawan, 1999).

Tetapi bahan baku mie berasal dari tepung terigu yang merupakan bahan impor dari luar negeri. Berdasarkan data BPS (2007), pada tahun 2003 impor terigu mencapai $343.144,9$ ton sedangkan tahun 2006 mencapai 536.961,6 ton meningkat 19 \%. Harga tepung terigu dari Rp. 3.613 per kg pada November 2007 naik menjadi Rp. 6.134 per $\mathrm{kg}$ pada Desember 2007 (Departemen Perdagangan, 2008) dan pada Januari 2008 mencapai Rp. 13.000 sampai Rp. 13.400 per kg. Hal ini sangat merugikan masyarakat banyak, sehingga perlu dilakukan penelitian untuk mencari bahan pengganti tepung terigu tersebut.

Ubi jalar menjadi salah satu bahan alternatif yang tepat untuk substitusi tepung terigu karena ubi jalar dapat menggantikan sumber karbohidrat yang ada pada tepung terigu. Disamping itu, ubi jalar banyak tumbuh di Indonesia dan hasilnya cukup melimpah. Menurut data FAO (2004), Indonesia merupakan negara penghasil ubi jalar ke 4 terbesar se-Dunia dengan produksi 1.859.744 ton. Dan berdasar data BPS (2007), produksi ubijalar di Indonesia pada tahun 2005 sebesar 1.856 .869 ton, pada tahun 2006 sebesar 1.854.238 ton, dan diprediksi pada triwulan ketiga tahun 2007 sebesar 1.874.036 ton. Berdasar data BPS tahun 2004, produktivitas ubi jalar Propinsi Jawa Tengah tahun 2002 sebesar 11,8 ton/ha. Disamping itu, ubi jalar juga merupakan sumber karbohidrat utama keempat setelah padi, jagung dan ubi kayu (Damardjati dan Widowati, 1993).

Walaupun hasilnya cukup melimpah, tetapi ubi jalar di Indonesia masih merupakan barang "inferior" bagi sebagian besar kalangan masyarakat di Indonesia, padahal ubi jalar kini populer di mancanegara sebagai bahan pangan yang kaya manfaat dan khasiat (Winneke, 2006). Ubi jalar menjadi salah satu alternatif yang tepat untuk substitusi tepung terigu tersebut karena disamping sebagai sumber karbohidrat, juga mengandung betakaroten, vitamin, kalsium, zat besi dan serat.

Ubi jalar yang digunakan adalah dalam bentuk kukus bukan dalam bentuk tepung. Hal ini dikarenakan pada penelitian pendahuluan yang telah dilakukan, hasil rendemen dari tepung ubi jalar kurang dari $10 \%$, sehingga dinilai tidak ekonomis bila dibandingkan dalam bentuk kukus. Dan disamping itu, penggunaan tepung ubi jalar menghasilkan mie kering yang kurang baik dalam hal kenampakannya bila dibandingkan dengan menggunakan ubi jalar dalam bentuk kukus.

Penggunaan ubi jalar yang digunakan untuk substitusi tepung terigu tersebut memiliki sedikit kekurangan yaitu rendahnya kandungan protein dibandingkan dengan tepung terigu. Berdasar Sarwono (2005), ubi jalar hanya mengandung protein 2,3\%. Sehingga untuk meningkatkan kandungan protein produk mie kering perlu adanya penambahan sumber protein. Berdasarkan Kanetro dan Hastuti (2006), semua jenis kacang-kacangan mempunyai potensi yang sama penyedia protein nabati yang relatif murah dan terjangkau oleh sebagian besar masyarakat di negara berkembang. Salah satu jenis kacang-kacangan tersebut antara lain adalah koro pedang (Canavalia ensiformis L. DC).

Koro pedang (Canavalia ensiformis L. DC) menjadi salah satu alternatif untuk meningkatkan kandungan protein karena mengandung protein yang tinggi. Menurut Kay (1979) dan Salunke Kadam (1989), kandungan gizi terutama kandungan protein yang terdapat dalam koro pedang yaitu sebesar 23,8 \% - 27,6 \%. Disamping itu, koro pedang merupakan salah satu jenis koro-koroan yang termasuk keluarga Leguminoceae dan merupakan jenis tanaman lokal (Widianarko, et al, 2003).

Berdasar uraian diatas, maka perlu dilakukan penelitian mengenai penggunaan ubi jalar 
untuk substitusi tepung terigu yang difortifikasi dengan tepung koro pedang dalam pembuatan mie kering. Adapun tujuan penelitian ini adalah mempelajari pengaruh substitusi ubi jalar dan pengayaan tepung koro pedang terhadap tepung terigu pada kandungan kimia dan sifat sensoris mie kering.

\section{METODE PENELITIAN}

\section{Bahan dan Alat}

Bahan yang digunakan dalam penelitian ini adalah ubi jalar lokal warna kuning orange dari Tawangmangu, koro pedang (Canavalia ensiformis L. DC) dibeli dari Pasar Legi, Solo, tepung terigu jenis hard (cap Cakra Kembar) dengan kadar protein $13-14 \%$, air aquades $\left(\mathrm{H}_{2} \mathrm{O}\right)$, garam $(\mathrm{NaCl})$, soda abu atau natrium karbonat $\left(\mathrm{Na}_{2} \mathrm{CO}_{3}\right)$ dan kalium karbonat $\left(\mathrm{K}_{2} \mathrm{CO}_{3}\right)$ 1:1 teknis. Sedangkan untuk bahan analisa proteinnya berupa pro analat meliputi asam sulfat pekat $\left(\mathrm{H}_{2} \mathrm{SO}_{4}\right)$, air raksa oksida $(\mathrm{HgO})$, larutan natrium hidroksida $(\mathrm{NaOH})$-natrium tiosulfat $\left(\mathrm{Na}_{2} \mathrm{~S}_{2} \mathrm{O}_{3}\right)$, kalium sulfat $\left(\mathrm{K}_{2} \mathrm{SO}_{4}\right)$, larutan asam borat jenuh $\left(\mathrm{Na}_{2} \mathrm{~B}_{4} \mathrm{O}_{7} \quad 10 \mathrm{H}_{2} \mathrm{O}\right)$ dan larutan asam klorida $(\mathrm{HCl}) 0,02 \mathrm{~N}$.

Alat yang digunakan dalam penelitian ini adalah alat pencetak mie, baskom plastik, kompor gas, wajan, bin dryer, cabinet dryer, blender dan peralatan untuk uji sensoris. Peralatan untuk analisa kadar air meliputi oven, cawan, desikator, penjepit cawan, timbangan digital. Peralatan untuk analisa kadar abu meliputi cawan pengabuan, tanur pengabuan dan penjepit cawan. Peralatan untuk analisa kadar protein meliputi pemanas kjeldahl, labu kjeldahl berukuran $30 \mathrm{ml} / 50 \mathrm{ml}$, alat distilasi lengkap dengan erlenmeyer berpenampung berukuran $125 \mathrm{ml}$, dan buret $25 \mathrm{ml} / 50 \mathrm{ml}$.

\section{Tahapan Penelitian}

Tahapan penelitian dimulai dengan membuat ubi jalar kukus, selanjutnya pembuatan tepung koro pedang dan terakhir pembuatan mie kering dengan beragam formula. Pembuatan ubi jalar kukus dimulai dengan mengupas ubi jalar, selanjutnya meniris ubi jalar lalu dicuci bersih dan dikukus selama 20 menit. Setelah dikukus ubi jalar dihancurkan hingga menjadi pasta. Sedangkan pembuatan koro pedang dimulai dengan koro pedang disortasi dan direndam selama 6 jam, lalu direbus selama 30 menit. Selanjutnya koro pedang dikupas dan dijemur di sinar matahari lalu dikeringkan dengan cabinet dryer selama 4 jam lalu dihancurkan dan diayak hingga 80 mesh. Tahap terakhir adalah membuat mie kering dengan menggunakan metode Antarlina (1997) yang dimodifikasi, dimulai dengan mencampur semua bahan (tepung terigu, ubi jalar kukus, tepung koro pedang, aquades, garam dan soda $a b u$ ), lalu diuleni dan dibentuk menjadi lembaran lalu dicetak menjadi mie. Mie dikukus selama 10 menit lalu dikeringkan selama 2 jam hingga menjadi mie kering.

\section{Rancangan Penelitian}

Penelitian ini menggunakan percobaan rancangan faktorial dengan 2 faktor perlakuan yaitu Faktor I : tepung campuran dengan sandi $\mathrm{T}$ terdiri dari 4 taraf yaitu : $\mathrm{T} 0=100 \%$ tepung terigu : $0 \%$ ubi jalar kukus; $\mathrm{T} 1=95 \%$ tepung terigu : $5 \%$ ubi jalar kukus;T2 $=90 \%$ tepung terigu : 10 $\%$ ubi jalar kukus; $\mathrm{T} 3=85 \%$ tepung terigu : $15 \%$ ubi jalar kukus dan Faktor II : Penambahan tepung koro pedang dengan sandi $\mathrm{K}$ terdiri dari 4 taraf yaitu : $\mathrm{K} 0=0 \%$; $\mathrm{K} 1=5 \% ; \mathrm{K} 2=10 \% ; \mathrm{K} 3=15 \%$ (dari tepung campuran). Sehingga didapat 16 kombinasi perlakuan. Masing-masing perlakuan diulang tiga kali.

\section{Metode Analisis}

Mie kering yang dihasilkan diuji sifat kimianya meliputi kadar air menggunakan metode oven (Apriyantono et al, 1989), kadar abu ditentukan dengan metode penetapan total abu (Apriyantono et al, 1989) dan kandungan protein ditentukan dengan metode kjeldahl-mikro (Apriyantono et al, 1989) serta uji kesukaan untuk parameter warna, rasa, aroma, elastisitas, dan keseluruhan dengan menggunakan 30 panelis tak terlatih (Kartika, et al, 1988).

\section{Analisis Data}

Selanjutnya, data yang diperoleh dianalisis dengan menggunakan ANOVA dan jika terdapat beda nyata dilanjutkan 
dengan uji DMRT dengan tingkat signifikansi 0,05. Analisis data dilakukan dengan mengaplikasikan software Excel dan SPSS 13.0.

\section{HASIL DAN PEMBAHASAN}

\section{A. Komposisi Kimia Mie Kering}

\section{Kadar Air Mie Kering}

Hasil analisis kadar air mie kering disajikan pada Tabel 1. Dari Tabel 1 dapat dilihat bahwa kadar air mie kering yang diperoleh berkisar $9 \%$ basis basah (bb). Hal ini sudah sesuai dengan SNI tahun 1992 yaitu kadar air yang dipersyaratkan untuk produk mie kering yaitu maksimal $10 \% \mathrm{bb}$.

Hasil analisis kadar air menunjukkan nilai kadar air mie kering berkisar antara 10$11 \%$ basis kering (bk). Kadar air mie kering T0K0 (10,101 \%) tidak berbeda nyata dengan kadar air mie kering T0K1, T0K2 dan T0K3 $(10,412 \%, 10,199 \%$ dan 10,086 \%). Sedangkan kadar air mie kering T1K2 $(10,204 \%)$ berbeda nyata dengan mie kering T1K0 (10,795 \%). Namun, kadar air mie kering T1K2 (10,204\%) menunjukkan tidak berbeda nyata dengan mie kering $\mathrm{T} 1 \mathrm{~K} 1$ dan T1K3 $(10,417 \%$ dan $10,484 \%)$. Hal ini dikarenakan dengan penambahan tepung koro pedang mengakibatkan penurunan kadar air mie kering. Menurut Milton dan Taylor (1969) enzim urease koro pedang memiliki kandungan asam amino leusin yang cukup tinggi. Dan disamping itu berdasar FAO (2008), koro pedang mengandung asam-asam amino, dimana asam amino leusin merupakan asam amino yang terbesar dalam koro pedang dibanding dengan asam amino yang lain yaitu sebesar $10,2 \%$. Asam amino leusin tersebut bersifat hidrofob (Nuringtyas, 2008). Bila protein mengandung banyak asam amino dengan gugus hidrofob, daya kelarutannya dalam air kurang baik dibandingkan dengan protein yang banyak mengandung asam amino dengan gugus hidrofil (Winarno, 2002). Sehingga dengan penambahan tepung koro pedang mengakibatkan penurunan kadar air mie kering.

\section{Kadar Abu Mie Kering}

Untuk hasil analisis kadar abu mie kering disajikan pada Tabel 1. Hasil analisis kadar abu tersebut dapat dinyatakan bahwa kadar abu yang diperoleh kombinasi perlakuan yang telah dilakukan berkisar $1 \%$ bb. Hasil ini sudah sesuai dengan SNI tahun 1992 mie kering yang ada yaitu kadar abu yang dipersyaratkan dalam produk mie kering adalah maksimal $3 \%$ bb.

Kadar abu mie kering T0K0 (1,335 $\%$ ) menunjukkan berbeda nyata dengan mie kering T0K2 dan T0K3 (1,556 \% dan 1,564 $\%$ ). Namun tidak berbeda nyata dengan mie kering T0K1 (1,430 \%). Koro pedang menurut Kay (1979) dan Salunkhe \& Kadam (1989) mengandung mineral 2,27-4,2 \%, sehingga jika koro pedang tersebut ditambahkan dengan konsentrasi bertingkat maka akan meningkatkan nilai kadar abu mie kering. Sedangkan kadar abu mie kering T1K0 (1,209 \%) menunjukkan berbeda nyata dengan mie kering T1K1, T1K2 dan T1K3 $(1,439 \%, 1,686 \%$ dan $1,641 \%)$. Koro pedang menurut Vadivel dan Janardhanan (2001) mengandung mineral 3-5,8 \% bk, sehingga jika koro pedang tersebut ditambahkan dengan konsentrasi bertingkat maka akan meningkatkan nilai kadar abu mie kering. Hasil penelitian ini sudah sesuai dengan Widyasrini (2008), bahwa semakin tinggi kara glinding yang digunakan dalam pembuatan mie basah, maka semakin meningkat pula kadar abu mie basah.

Sedangkan, kadar abu mie kering T3K2 (1,809 \%) menunjukkan berbeda nyata dengan mie kering T0K2 (1,556 \%), namun tidak berbeda nyata dengan mie kering T1K2 dan T2K2 (1,686\% dan 1,652\%). Kadar abu mie kering T2K3 (1,855 \%) menunjukkan berbeda nyata dengan mie kering T0K3 dan T1K3 (1,564 \% dan 1,641 $\%$, namun tidak berbeda nyata dengan mie kering T3K3 (1,779\%).

\section{Kadar Protein Mie Kering}

Hasil analisis kadar protein disajikan pada Tabel 1. Hasil analisis kadar protein tersebut dapat dinyatakan bahwa kadar protein mie kering yang diuji berkisar antara 13-17 \%. Hasil penelitian ini sudah sesuai 
Tabel 1. Karakteristik Kimia Berbagai Kombinasi Perlakuan

\begin{tabular}{|c|c|c|c|}
\hline Sampel & $\begin{array}{l}\text { Kadar Air } \\
(\% \text { bk) }\end{array}$ & $\begin{array}{l}\text { Kadar Abu } \\
(\% \text { bk) }\end{array}$ & $\begin{array}{l}\text { Kadar Protein } \\
(\% \mathrm{bk})\end{array}$ \\
\hline T0K0 & $10,101 \mathrm{ab}$ & $1,335 \mathrm{ab}$ & 14, \\
\hline T0K1 & $10,412 \mathrm{abcd}$ & $1,430 \mathrm{bc}$ & $16,222 \mathrm{ab}$ \\
\hline T0K2 & $10,199 \mathrm{abc}$ & 1,556 cde & $16,222 \mathrm{ab}$ \\
\hline T0K3 & $10,086 \mathrm{a}$ & 1,564 cde & $17,518 \mathrm{bcd}$ \\
\hline TIK0 & $10,795 \mathrm{de}$ & $1,209 \mathrm{a}$ & $16,801 \mathrm{abc}$ \\
\hline $\mathrm{T} 1 \mathrm{~K} 1$ & $10,417 \mathrm{abcd}$ & $1,439 \mathrm{bc}$ & $18,166 \mathrm{bcd}$ \\
\hline $\mathrm{T} 1 \mathrm{~K} 2$ & $10,204 \mathrm{abc}$ & 1,686 efg & $17,518 \mathrm{bcd}$ \\
\hline $\mathrm{T} 1 \mathrm{~K} 3$ & $10,484 \mathrm{abcd}$ & $1,641 \mathrm{def}$ & $14 \mathrm{~cd}$ \\
\hline $\mathrm{T} 2 \mathrm{~K} 0$ & $10,500 \mathrm{abcd}$ & 1,652 defg & $16,801 \mathrm{abc}$ \\
\hline T2K1 & $1 \mathrm{~cd}$ & 1,660 defg & $184 \mathrm{bcd}$ \\
\hline $\mathrm{T} 2 \mathrm{~K} 2$ & 10,1 & defg & 4 bcd \\
\hline $\mathrm{T} 2 \mathrm{~K} 3$ & abcd & 1,85 & $19,463 \mathrm{~d}$ \\
\hline T3K0 & 11,0 & $1,503 \mathrm{~cd}$ & 370 abc \\
\hline T3K1 & abc & $1,780 \mathrm{fgh}$ & $18,166 \mathrm{bcd}$ \\
\hline T3K2 & bcd & $1,809 \mathrm{gh}$ & $17,554 \mathrm{bcd}$ \\
\hline $\mathrm{T} 3 \mathrm{~K} 3$ & $10,412 \mathrm{abcd}$ & $1,779 \mathrm{fgh}$ & $19,463 \mathrm{~d}$ \\
\hline $\begin{array}{l}\text { Huruf y } \\
\text { nyata pac } \\
\text { Keterang } \\
\text { T0K0: }\end{array}$ & $\begin{array}{l}\text { sama dibelaka } \\
\text { araf } 5 \% \\
\% \text { tepung terig } \\
\text { pedang }\end{array}$ & \multicolumn{2}{|c|}{$\begin{array}{l}\text { Huruf yang sama dibelakang angka menyatakan tidak berbeda } \\
\text { nyata pada taraf } 5 \% \\
\text { Keterangan. }\end{array}$} \\
\hline \multicolumn{4}{|c|}{$\begin{array}{l}\text { T0K1 : } 100 \% \text { tepung terigu : } 0 \% \text { ubi jalar kukus : } 5 \% \text { tepung } \\
\text { koro pedang }\end{array}$} \\
\hline \multicolumn{4}{|c|}{$\begin{array}{l}\text { T0K2 : } 100 \% \text { tepung terigu : } 0 \% \text { ubi jalar kukus : } 10 \% \text { tepung } \\
\text { koro pedang }\end{array}$} \\
\hline \multicolumn{4}{|c|}{$\begin{aligned} \text { T0K3 : } & 100 \% \text { tepung terigu : } 0 \% \text { ubi jalar kukus : } 15 \% \text { tepung } \\
& \text { koro pedang }\end{aligned}$} \\
\hline \multicolumn{4}{|c|}{$\begin{array}{l}\text { T1K0:95\% tepung terigu:5\% ubi jalar kukus: } 0 \% \text { tepung koro } \\
\text { pedang }\end{array}$} \\
\hline \multicolumn{4}{|c|}{$\begin{array}{l}\mathrm{T} 1 \mathrm{~K} 1: 95 \% \text { tepung terigu : } 5 \% \text { ubi jalar kukus : } 5 \% \text { tepung koro } \\
\text { pedang }\end{array}$} \\
\hline \multicolumn{4}{|c|}{$\begin{array}{l}\text { T1K2 : } 95 \% \text { tepung terigu : } 5 \% \text { ubi jalar kukus : } 10 \% \text { tepung } \\
\text { koro pedang }\end{array}$} \\
\hline \multicolumn{4}{|c|}{$\begin{array}{l}\text { T1K3 : } 95 \% \text { tepung terigu : } 5 \% \text { ubi jalar kukus : } 15 \% \text { tepung } \\
\text { koro pedang }\end{array}$} \\
\hline \multicolumn{4}{|c|}{$\begin{array}{l}\mathrm{T} 2 \mathrm{~K} 0: 90 \% \text { tepung terigu : } 10 \% \text { ubi jalar kukus : } 0 \% \text { tepung } \\
\text { koro pedang }\end{array}$} \\
\hline \multicolumn{4}{|c|}{$\begin{array}{l}\mathrm{T} 2 \mathrm{~K} 1: 90 \% \text { tepung terigu : } 10 \% \text { ubi jalar kukus : } 5 \% \text { tepung } \\
\text { koro pedang }\end{array}$} \\
\hline \multicolumn{4}{|c|}{$\begin{aligned} \mathrm{T} 2 \mathrm{~K} 2: & 90 \% \text { tepung } \\
& \text { koro pedang }\end{aligned}$} \\
\hline \multicolumn{4}{|c|}{$\begin{aligned} \mathrm{T} 2 \mathrm{~K} 3: & 90 \% \text { tepung } \\
& \text { koro pedang }\end{aligned}$} \\
\hline & \multicolumn{3}{|c|}{$\begin{aligned} \text { T3K0 }: & 85 \% \text { tepung } \\
& \text { koro pedang }\end{aligned}$} \\
\hline \multicolumn{4}{|c|}{$\begin{aligned} \mathrm{T} 3 \mathrm{~K} 1: & 85 \% \text { tepung terig } \\
& \text { koro pedang }\end{aligned}$} \\
\hline $\mathrm{T} 3 \mathrm{~K} 2: 85 \%$ tepung terigu & $\begin{array}{l}0 \text { tepung terigu } \\
\text { pedang }\end{array}$ & & kus : $10 \%$ tepung \\
\hline $\mathrm{T} 3 \mathrm{~K} 3:$ & $\%$ tepung terigu & & kus : $15 \%$ tepung \\
\hline
\end{tabular}

dengan SNI yang ada yaitu untuk kadar protein mie kering minimal $8 \% \mathrm{bb}$.

Kadar protein mie kering T0K3 (17,518 \%) menunjukkan berbeda nyata dengan mie kering T0K0 (14,926 \%), namun jika dibandingkan dengan mie kering T0K1 dan T0K2 $\quad(16,222 \quad \% \quad$ dan $\quad 16,222 \quad \%)$ menunjukkan tidak berbeda nyata. Menurut Kay (1979) dan Salunkhe \& Kadam (1989), koro pedang mengandung protein sebesar 23,8-27,6 \% sehingga penambahan tepung koro pedang yang semakin meningkat mengakibatkan peningkatan kadar protein mie kering. Hasil penelitian ini sudah sesuai dengan Widyasrini (2008), bahwa semakin tinggi kara glinding yang digunakan dalam pembuatan mie basah, maka semakin meningkat pula kadar protein mie basah.

\section{B. Uji Sensoris Mie Kering}

\section{Warna Mie Kering}

Dari hasil uji sensoris terhadap atribut warna mie kering, secara umum panelis memberikan nilai kurang suka hingga suka pada mie kering sampel yaitu dengan rata-rata penilaian 2,27-3,20. Untuk mie kering kontrol (T0K0) panelis memberikan penilaian suka yaitu dengan nilai rata-rata sebesar 3,23.

Nilai warna sampel mie kering kontrol (T0K0) berbeda nyata dengan nilai warna sampel mie kering T0K1, T0K2 dan TOK3. Hal ini dikarenakan warna tepung koro pedang yang cenderung putih kecoklatan tersebut akan menimbulkan warna mie kering menjadi kuning pucat. Penambahan tepung koro pedang secara bertingkat tersebut akan mengakibatkan warna mie kering semakin kuning pucat. Warna kuning pucat tersebut menurunkan penilaian panelis terhadap warna mie kering.

Nilai warna sampel mie kering kontrol (T0K0) berbeda nyata dengan nilai warna sampel mie kering T2K0 dan T3K0, namun tidak berbeda nyata dengan sampel mie kering T1K0. Hal ini dikarenakan penambahan ubi jalar kukus sebanyak $5 \%$ (T1K0) tersebut belum terlalu mempengaruhi warna mie kering yang dihasilkan sehingga nilai warnanya tidak berbeda nyata dibandingkan dengan mie kering kontrol (T0K0). Tetapi dengan penambahan ubi jalar kukus lebih dari $5 \%$, menyebabkan warna mie kering menjadi kuning orange. Pada umumnya mie kering di pasaran berwarna kuning, sedangkan warna mie kering sampel berwarna kuning orange. Warna mie kering kuning orange tersebut menurunkan penilaian panelis terhadap warna mie kering. Warna kuning orange dari ubi jalar tersebut diakibatkan oleh karotenoid. Karotenoid merupakan kelompok pigmen yang berwarna kuning. 
Karotenoid terdapat dalam buah pepaya, kulit pisang, tomat, cabai merah, mangga, wortel, ubi jalar dan pada beberapa bunga yang berwarna kuning dan merah (Winarno, 2002).

\section{Rasa Mie Kering}

Dari hasil uji sensoris terhadap atribut rasa mie kering, secara umum panelis memberikan nilai kurang suka pada mie kering sampel yaitu dengan rata-rata penilaian 2,33-2,90. Untuk mie kering kontrol (T0K0) panelis memberikan penilaian suka yaitu dengan nilai rata-rata sebesar 3,20. Nilai rasa sampel mie kering kontrol (T0K0) berbeda nyata dengan nilai rasa sampel mie kering $\mathrm{T} 0 \mathrm{~K} 1$, T0K2 dan T0K3. Hal ini dikarenakan penambahan tepung koro pedang secara bertingkat mengakibatkan mie kering yang dihasilkan memiliki rasa yang kurang disukai oleh panelis. Rasa yang kurang disukai oleh panelis tersebut dikarenakan rasa khas kacang-kacangan yang terdapat pada tepung koro pedang.

Nilai rasa sampel mie kering kontrol (T0K0) berbeda nyata dengan nilai rasa sampel mie kering $\mathrm{T} 1 \mathrm{~K} 0$, T2K0 dan T3K0. Hal ini dikarenakan, penambahan ubi jalar kukus tersebut secara bertingkat menimbulkan rasa khas ubi jalar pada mie kering, sehingga menurunkan penilaian panelis terhadap rasa. Nilai rasa sampel mie kering T0K1 tidak berbeda nyata dengan nilai rasa sampel mie kering $\mathrm{T} 1 \mathrm{~K} 1, \mathrm{~T} 2 \mathrm{~K} 1$ dan T3K1. Nilai rasa sampel mie kering T0K2 tidak berbeda nyata dengan nilai rasa sampel mie kering T1K2, T2K2 dan T3K2. Nilai rasa sampel mie kering T0K3 tidak berbeda nyata dengan nilai rasa sampel mie kering T1K3, T2K3 dan T3K3.

\section{Aroma Mie Kering}

Dari hasil uji sensoris terhadap atribut aroma mie kering, secara umum panelis memberikan nilai kurang suka pada mie kering sampel yaitu dengan rata-rata penilaian 2,40-2,90. Untuk mie kering kontrol (T0K0) panelis memberikan penilaian suka yaitu dengan nilai rata-rata sebesar 3,03. Nilai aroma sampel mie kering kontrol (T0K0) berbeda nyata dengan nilai aroma sampel mie kering T0K2 dan T0K3, namun tidak berbeda nyata dengan sampel mie kering T0K1. Hal ini dikarenakan dengan penambahan tepung koro pedang sebanyak $5 \%$ tesebut (T0K1) belum menimbulkan bau langu pada mie kering sehingga penilaian panelis terhadap aroma tidak berbeda nyata dibanding dengan sampel mie kering kontrol (T0K0). Tetapi berbeda halnya jika tepung koro pedang yang ditambahkan lebih dari $5 \%$ (T0K2 dan T0K3), maka membuat mie kering yang dihasilkan agak berbau langu, dikarenakan beany flavour yang ada pada koro pedang tersebut. Dengan bau langu tersebut menimbulkan penurunan panelis terhadap aroma mie kering dan berbeda nyata dengan sampel mie kering kontrol (T0K0).

$$
\text { Lipoksigenase }
$$

(linoleat

oksidoreduktase) banyak dijumpai pada tanaman kacang-kacangan. Enzim ini mengatalisa reaksi pembentukan hidroperoksida dari asam linoleat atau asam lemak poliunsaturasi lain yang memiliki sistem ikatan rangkap cis-cis-1,4-pentadiena dengan adanya oksigen. Asam lemak utama pada kacang-kacangan adalah asam lemak tidak jenuh yaitu linoleat, sehingga memudahkan terjadinya oksidasi asam lemak tersebut bila kacang tersebut terkena aksi.

Produk oksidasi awal dari aktivitas lipoksigenase dapat mengalami degradasi menjadi senyawa dengan atom C-6 dan C-9 melalui isomerasi dan atau lyases hidroperoksida. Senyawa-senyawa yang bersifat volatil tersebut adalah aldehid, keton, dan alkohol. Beberapa senyawa tersebut menyebabkan timbulnya flavor yang tidak diinginkan/off flavor atau lebih dikenal dengan beany flavor atau langu (Liu, 1999 cit Kanetro dan Hastuti, 2006).

Nilai aroma sampel mie kering kontrol (T0K0) berbeda nyata dengan nilai aroma sampel mie kering $\mathrm{T} 2 \mathrm{~K} 0$ dan $\mathrm{T} 3 \mathrm{~K} 0$, namun tidak berbeda nyata dengan sampel mie kering T1K0. Hal ini dikarenakan dengan penambahan ubi jalar kukus sebanyak $5 \%$ tesebut (T1K0) belum menimbulkan bau ubi jalar pada mie kering sehingga penilaian panelis terhadap aroma tidak berbeda nyata dibanding dengan sampel mie kering kontrol (T0K0). Tetapi 
Tabel 2. Hasil Uji Kesukaan Mie Kering dari Beberapa Kombinasi Perlakuan

\begin{tabular}{llllll}
\hline \multirow{2}{*}{ Sampel } & \multicolumn{5}{c}{ Atribut Mutu } \\
\cline { 2 - 6 } & Warna & Rasa & Aroma & Elastisitas & Keseluruhan \\
\hline T0K0 & $3,23 \mathrm{e}$ & $3,20 \mathrm{f}$ & $3,03 \mathrm{e}$ & $3,07 \mathrm{c}$ & $3,00 \mathrm{~d}$ \\
T0K1 & $2,60 \mathrm{bcd}$ & $2,67 \mathrm{abcde}$ & $2,90 \mathrm{de}$ & $2,90 \mathrm{bc}$ & $2,80 \mathrm{~cd}$ \\
T0K2 & $2,27 \mathrm{a}$ & $2,53 \mathrm{abcd}$ & $2,67 \mathrm{abcd}$ & $2,50 \mathrm{a}$ & $2,43 \mathrm{ab}$ \\
T0K3 & $2,33 \mathrm{ab}$ & $2,40 \mathrm{ab}$ & $2,57 \mathrm{abc}$ & $2,50 \mathrm{a}$ & $2,50 \mathrm{abc}$ \\
TIK0 & $3,20 \mathrm{e}$ & $2,90 \mathrm{e}$ & $2,83 \mathrm{cde}$ & $2,60 \mathrm{ab}$ & $2,80 \mathrm{~cd}$ \\
T1K1 & $2,60 \mathrm{bcd}$ & $2,70 \mathrm{bcde}$ & $2,70 \mathrm{abcd}$ & $2,61 \mathrm{ab}$ & $2,60 \mathrm{abc}$ \\
T1K2 & $2,37 \mathrm{abc}$ & $2,47 \mathrm{abc}$ & $2,57 \mathrm{abc}$ & $2,43 \mathrm{a}$ & $2,33 \mathrm{a}$ \\
T1K3 & $2,57 \mathrm{abcd}$ & $2,43 \mathrm{abc}$ & $2,50 \mathrm{ab}$ & $2,50 \mathrm{a}$ & $2,40 \mathrm{ab}$ \\
T2K0 & $2,80 \mathrm{~d}$ & $2,87 \mathrm{de}$ & $2,70 \mathrm{abcd}$ & $2,53 \mathrm{a}$ & $2,67 \mathrm{bc}$ \\
T2K1 & $2,67 \mathrm{~cd}$ & $2,67 \mathrm{abcde}$ & $2,67 \mathrm{abcd}$ & $2,60 \mathrm{ab}$ & $2,60 \mathrm{abc}$ \\
T2K2 & $2,57 \mathrm{abcd}$ & $2,63 \mathrm{abcde}$ & $2,60 \mathrm{abc}$ & $2,43 \mathrm{a}$ & $2,63 \mathrm{abc}$ \\
T2K3 & $2,53 \mathrm{abcd}$ & $2,50 \mathrm{abc}$ & $2,57 \mathrm{abc}$ & $2,43 \mathrm{a}$ & $2,53 \mathrm{abc}$ \\
T3K0 & $2,77 \mathrm{~d}$ & $2,77 \mathrm{cde}$ & $2,67 \mathrm{abcd}$ & $2,50 \mathrm{a}$ & $2,67 \mathrm{bc}$ \\
T3K1 & $2,70 \mathrm{~d}$ & $2,70 \mathrm{bcde}$ & $2,73 \mathrm{bcd}$ & $2,67 \mathrm{ab}$ & $2,63 \mathrm{abc}$ \\
T3K2 & $2,53 \mathrm{abcd}$ & $2,63 \mathrm{abcde}$ & $2,73 \mathrm{bcd}$ & $2,47 \mathrm{a}$ & $2,70 \mathrm{bc}$ \\
T3K3 & $2,53 \mathrm{abcd}$ & $2,33 \mathrm{a}$ & $2,40 \mathrm{a}$ & $2,40 \mathrm{a}$ & $2,67 \mathrm{bc}$ \\
\hline
\end{tabular}

Huruf yang sama dibelakang angka menyatakan tidak berbeda nyata pada taraf $5 \%$

Keterangan atribut mutu : 1 = tidak suka; 2 = kurang suka; $3=$ suka; $4=$ lebih suka; $5=$ sangat suka

Keterangan:

T0K0 : $100 \%$ tepung terigu : $0 \%$ ubi jalar kukus : $0 \%$ tepung koro pedang

T0K1 : $100 \%$ tepung terigu : $0 \%$ ubi jalar kukus : $5 \%$ tepung koro pedang

T0K2 : $100 \%$ tepung terigu : $0 \%$ ubi jalar kukus : $10 \%$ tepung koro pedang

T0K3 : $100 \%$ tepung terigu : $0 \%$ ubi jalar kukus : $15 \%$ tepung koro pedang

T1K0 : $95 \%$ tepung terigu : $5 \%$ ubi jalar kukus : $0 \%$ tepung koro pedang

T1K1 : $95 \%$ tepung terigu : $5 \%$ ubi jalar kukus : $5 \%$ tepung koro pedang

T1K2 : $95 \%$ tepung terigu : $5 \%$ ubi jalar kukus : $10 \%$ tepung koro pedang

T1K3 : $95 \%$ tepung terigu : $5 \%$ ubi jalar kukus : $15 \%$ tepung koro pedang

T2K0 : $90 \%$ tepung terigu : $10 \%$ ubi jalar kukus : $0 \%$ tepung koro pedang

T2K1 : $90 \%$ tepung terigu : $10 \%$ ubi jalar kukus : $5 \%$ tepung koro pedang

T2K2 : $90 \%$ tepung terigu : $10 \%$ ubi jalar kukus : $10 \%$ tepung koro pedang

T2K3 : $90 \%$ tepung terigu : $10 \%$ ubi jalar kukus : $15 \%$ tepung koro pedang

T3K0 : $85 \%$ tepung terigu : $15 \%$ ubi jalar kukus : $0 \%$ tepung koro pedang

T3K1 : $85 \%$ tepung terigu : $15 \%$ ubi jalar kukus : $5 \%$ tepung koro pedang

T3K2 : $85 \%$ tepung terigu : $15 \%$ ubi jalar kukus : $10 \%$ tepung koro pedang

T3K 3 : $85 \%$ tepung terigu : $15 \%$ ubi jalar kukus : $15 \%$ tepung koro pedang

berbeda halnya jika ubi jalar kukus yang ditambahkan lebih dari $5 \%$ (T2K0 dan T3K0), maka membuat mie kering yang dihasilkan agak berbau ubi jalar yang khas. Dengan bau ubi jalar yang khas tersebut menimbulkan penurunan panelis terhadap aroma mie kering dan berbeda nyata dengan sampel mie kering kontrol (T0K0). Nilai aroma sampel mie kering TOK1 tidak berbeda nyata dengan nilai aroma sampel mie kering T1K1, T2K1 dan T3K1. Nilai aroma sampel mie kering T0K2 tidak berbeda nyata dengan nilai aroma sampel mie kering T1K2, T2K2 dan T3K2. Nilai aroma sampel mie kering T0K3 tidak berbeda nyata dengan nilai aroma sampel mie kering T1K3, T2K3 dan T3K3.

\section{Elastisitas Mie Kering}

Dari hasil uji sensoris terhadap atribut elastisitas mie kering, secara umum panelis memberikan nilai kurang suka pada mie kering sampel yaitu dengan rata-rata penilaian 2,40-2,90. Untuk mie kering kontrol (T0K0) panelis memberikan penilaian suka yaitu dengan nilai rata-rata sebesar 3,07. Nilai elastisitas sampel mie kering kontrol (T0K0) berbeda nyata dengan nilai elastisitas sampel mie kering T0K2 dan T0K3, namun tidak berbeda nyata dengan 
sampel mie kering T0K1. Hal ini dikarenakan dengan penambahan tepung koro pedang sebanyak $5 \%$ tesebut (T0K1) belum mengurangi elastisitas mie kering sehingga penilaian panelis terhadap elastisitas tidak berbeda nyata dibanding dengan sampel mie kering kontrol (T0K0). Tetapi berbeda halnya jika tepung koro pedang yang ditambahkan lebih dari $5 \%$ (T0K2 dan T0K3), maka membuat mie kering yang dihasilkan mudah putus atau kurang elastis. Hal ini dikarenakan tepung terigu menurut Astawan (1999), memiliki kemampuan untuk membentuk gluten pada saat terigu dibasahi dengan air. Sifat elastis gluten pada adonan mie menyebabkan mie yang dihasilkan tidak mudah putus pada proses pencetakan dan pemasakan. Jika penggunaan terigu tersebut dikurangi dan diganti dengan penambahan tepung koro pedang maka mengakibatkan mie yang dihasilkan mudah putus dan menurunkan penilaian panelis terhadap elastisitas. Karena tepung koro pedang tidak memiliki kemampuan untuk membentuk gluten seperti halnya tepung terigu, sehingga menyebabkan mie yang dihasilkan mudah putus.

Nilai elastisitas sampel mie kering kontrol (T0K0) berbeda nyata dengan nilai elastisitas sampel mie kering $\mathrm{T} 1 \mathrm{~K} 0$, T2K0 dan T3K0. Hal ini dikarenakan tepung terigu menurut Astawan (1999), memiliki kemampuan untuk membentuk gluten pada saat terigu dibasahi dengan air. Sifat elastis gluten pada adonan mie menyebabkan mie yang dihasilkan tidak mudah putus pada proses pencetakan dan pemasakan. Jika penggunaan terigu tersebut dikurangi dan diganti dengan penambahan ubi jalar kukus maka mengakibatkan mie yang dihasilkan mudah putus dan menurunkan penilaian panelis terhadap elastisitas. Karena ubi jalar memiliki kandungan protein yang rendah, menurut Sarwono (2005), ubi jalar mengandung protein $2,3 \mathrm{gr} / 100$ gr dan tidak memiliki kemampuan untuk membentuk gluten seperti halnya tepung terigu, sehingga menyebabkan mie yang dihasilkan mudah putus. Nilai elastisitas sampel mie kering T0K1 tidak berbeda nyata dengan nilai elastisitas sampel mie kering $\mathrm{T} 1 \mathrm{~K} 1, \mathrm{~T} 2 \mathrm{~K} 1$ dan T3K1. Nilai elastisitas sampel mie kering T0K2 tidak berbeda nyata dengan nilai elastisitas sampel mie kering $\mathrm{T} 1 \mathrm{~K} 2$, T2K2 dan T3K2. Nilai elastisitas sampel mie kering T0K3 tidak berbeda nyata dengan nilai rasa sampel mie kering $\mathrm{T} 1 \mathrm{~K} 3$, T2K3 dan T3K3.

\section{Keseluruhan Mie Kering}

Nilai keseluruhan mie kering yang diberikan oleh panelis menentukan prosentase penggunaan tepung terigu, ubi jalar kukus dan tepung koro pedang yang akan digunakan untuk membuat mie kering yang masih dapat diterima oleh konsumen. Sedangkan, sampel mie kering yang secara keseluruhan tidak berbeda nyata dengan mie kering kontrol adalah $\mathrm{T} 0 \mathrm{~K} 1$ dan $\mathrm{T} 1 \mathrm{~K} 0$. Hal ini dikarenakan, sampel mie kering T0K1 tersebut dari 2 penilaian atribut mutu sebelumnya (aroma dan elastisitas) menunjukkan hasil yang tidak berbeda nyata dengan sampel mie kering kontrol (TOK0), Ini membuktikan bahwa faktor atribut mutu yang mempengaruhi panelis dalam menilai keseluruhan sampel mie kering T0K1 dibandingkan T0K0 adalah atribut mutu aroma dan elastisitas. Sedangkan, sampel mie kering $\mathrm{T} 1 \mathrm{~K} 0$ tidak berbeda nyata dengna mie kering kontrol (T0K0) karena sampel mie kering $\mathrm{T} 1 \mathrm{~K} 0$ tersebut dari 2 penilaian atribut mutu sebelumnya (warna dan aroma) menunjukkan hasil yang tidak berbeda nyata dengan sampel mie kering kontrol (T0K0), Ini membuktikan bahwa faktor atribut mutu yang mempengaruhi panelis dalam menilai keseluruhan sampel mie kering T1K0 dibandingkan T0K0 adalah atribut mutu warna dan aroma.

\section{KESIMPULAN}

Kesimpulan yang dapat diambil dari penelitian ini adalah sebagai berikut :

1. Semakin tinggi penambahan ubi jalar kukus yang digunakan, maka semakin tinggi pula kadar air dan kadar abu mie kering, tetapi semakin rendah kadar protein mie kering serta semakin menurunkan penilaian panelis terhadap warna, rasa, aroma, elastisitas dan keseluruhan mie kering. 
2. Semakin tinggi penambahan tepung koro pedang yang digunakan, maka semakin tinggi pula kadar protein dan kadar abu mie kering, tetapi semakin rendah kadar air mie kering serta semakin menurunkan penilaian penelis terhadap warna, rasa, aroma, elastisitas dan keseluruhan mie kering.

3. Mie kering dengan formulasi $100 \%$ tepung terigu, $0 \%$ ubi jalar kukus dan 5 $\%$ tepung koro pedang (T0K1) dan mie kering formulasi $95 \%$ tepung terigu, $5 \%$ ubi jalar kukus dan $0 \%$ tepung koro pedang (T1K0) mendapatkan penilaian panelis dari segi keseluruhan tidak berbeda nyata dengan mie kering kontrol (T0K0).

\section{DAFTAR PUSTAKA}

Astawan, M., 1999. Membuat Mie dan Bihun. Penebar Swadaya, Jakarta.

BPS, 2006. Badan Pusat Statistik, Jakarta.

, 2007. Badan Pusat Statistik, Jakarta.

Departemen Perdagangan, 2008. dalam

Kompas 3 Januari 2008.

FAO, 2004. dalam Ubi Jalar Cara Budi Daya Yang Tepat. Efisien, dan Ekonomis. Penebar Swadaya. Depok.

Damardjati, D.S dan S. Widowati 1993. Pemanfaatan Ubi Jalar Dalam Program Diversifikasi Guna Mensukseskan Swasembada Pangan. Dalam Ringkasan Makalah Seminar Penerapan Teknologi Produksi dan Pasca Panen Ubi Jalar Untuk Mendukung Agro Industri. Balittan Malang dan FP UNIBRAW Malang.

Wineke, O., 2006. Sariumbi, Tepung Ubi Jalar Berkhasiat. http://www.detikfood.com, diakses tanggal 29 Februari 2008.

Sarwono, B., 2005. Ubi Jalar Cara Budi Daya Yang Tepat. Efisien, dan Ekonomis. Penebar Swadaya. Depok

Kanetro, B. dan S. Hastuti, 2006. Ragam Produk Olahan Kacang-kacangan. CV. Debut Wahana Sinergi, Yogyakarta.
Salunkhe, D.K., dan S.S. Kadam, 1985. Handbook of World Food Legumes : Nutritional Chemistry, Processing Technology, and utilization. Volume II. CRC Press Inc. Florida dalam Menuai Polong Sebuah Pengalaman Advokasi keragaman Hayati. PT. Grasindo. Jakarta.

Widianarko, B., R. Pratiwi, Soedarini, R. Dewi, S. Wahyuningsih dan N. Sulistyani, 2003. Menuai Polong Sebuah Pengalaman Advokasi keragaman Hayati. PT. Grasindo. Jakarta.

Milton, J.M dan I. E. P. Taylor, 1969. The Amino Acid Composition of Jack-Bean Urease. Department of Botany, University of Liverpool. Liverpool.

FAO, 2008. Canavalia ensiformis Jack bean, Sword Bean. http://www.fao.org/ag/aGa/agap/FRG/ AFRIS/Data/207.htm. diakses pada tanggal 17 September 2008.

Winarno, F.G, 2002. Kimia Pangan dan Gizi. PT Gramedia Pustaka Utama. Jakarta.

Vadivel, V and K. Janardhanan, 2001. Diversity in nutritional composition of wild jack bean (Canavalia ensiformis L. DC) seeds collected from south India. Food Chemistry. Volume 74, Issue 4, September 2001, Pages 507511. dalam http://www.sciencedirect.com, diakses tanggal 25 Februari 2008.

Widyasrini, Ari, 2008. Pengaruh Penambahan Tepung Koro Glinding (Phaseolus lunatus) Terhadap Sifat Kimia dan Organoleptik Mi Basah Dengan Bahan Baku Tepung Terigu Yang Disubstitusi Tepung Ubi Jalar Ungu (Ipomoea batatas). Skripsi S1 Fakultas Pertanian UNS. Surakarta 